\title{
LAW AND THE SPACE OF APPEARANCE IN ARENDT'S THOUGHT
}

\author{
Johan van der Walt*
}

\section{INTRODUCTION}

\begin{abstract}
"A life spent entirely in public, in the presence of others, becomes, as we would say, shallow. While it retains its visibility, it loses the quality of rising into sight from some darker ground which must remain hidden if it is not to lose its depth in a very real, non-subjective sense. The only efficient way to guarantee the darkness of what needs to be hidden against the light of publicity is private property, a privately owned place to hide in."
\end{abstract}

The concern with the appearance of the world in human consciousness, the fundamental concern of the tradition of European philosophical inquiry that came to be called phenomenology, runs like a constant thread through Hannah Arendt's work. But this passage from The Human Condition marks the specificity of Arendt's place within the phenomenological tradition. It marks the way she focused the phenomenological concern with the appearance of the world on the way the world comes to light when political action sets forth and leaves behind the private concerns of the home. The central aim of this essay will be to illuminate this specificity of Arendt's contribution to phenomenology in terms of a fundamental phenomenology of law. In pursuit of this aim it will also highlight resonances in Arendt's work with two other major phenomenologists of her time, namely Martin Heidegger and Maurice Merleau-Ponty. ${ }^{2}$

The reading of Arendt that will be expounded in this essay will proceed as follows: Section II (Appearance, Reality, Truth) explains what is at stake when phenomenology turns its attention to the phenomenon, to that which appears. Section III (Appearing: The Phainesthai of the Phenomenon) illuminates the kinetic trajectory that informs the word "appearance". Appearance concerns the transitory, intransitive or in-transit interim of a (this or that) coming to light of the world from the dark margins of consciousness into the illuminated centre of human intentionality.

Section IV (The Shadow and its Shade) turns to Arendt's engagement with the phenomenon of poverty. Arendt understood well that poverty appears and indeed appeared in epochal fashion in the modern age. She nevertheless did not consider the appearance of poverty as part of the proper space of appearance constituted by politics. Poverty was not for Arendt a proper political concern. Phenomenologically speaking, this refusal to regard poverty and bodily needs as a political concern constituted a remarkable failure to engage perceptively with one of the essential

\footnotetext{
* Professor of Law, University of Glasgow. I am grateful to everyone who participated in the workshop on Arendt and the Law in Antwerp, June 2010. Many helpful comments during the workshop helped me to improve the original draft of this essay substantially. Responsibility for errors and misunderstandings of course remain strictly mine.

${ }^{1}$ Hannah Arendt The Human Condition (Chicago/London, University of Chicago Press, 1989) 71.

${ }^{2}$ Heidegger's influence on Arendt is well-known and visible in almost all her works, notwithstanding the very different and quite opposite positions she takes in with regard to many common concerns in their respective oeuvres. As a fascinating letter from Arendt to Heidegger reveals, she discovered Merleau-Ponty very late in her life (cf. Hannah Arendt and Martin Heidegger Hannah Arendt Martin Heidegger Briefe (Frankfurt am Main, Vitttorio Klostermann, 1999) 225), but from that moment on she relied substantially on his thinking and clearly recognised the phenomenological roots which they shared.
} 
phenomena of her time. This remarkable failure nevertheless went hand in hand with a profound insight, the insight the private domain must shield from politics the existential concerns of the human heart. The concerns of the heart not only need protection from public scrutiny. It exists as such by virtue of the desire to withdraw from everything that has become public. It can therefore not and should not be the concern of politics. This is the profound counter-side of her spurious thought that poverty is not a political concern.

Section V (The Literary Exception) turns to the place of the law in Arendt's thought. The law would seem to be an endpoint for Arendt, a culmination of self-evidence, a termination of appearance. She seems to espouse an understanding of natural law and natural legal principles that already govern polities prior to the positive political articulation of the law. This is evident from her insistence that political revolution is fundamentally a matter of restoring timeless principles of law that exist prior to their revolutionary enactments. Law thus seems to be exempted from the space of appearance. The law does not appear, it always exists already fully apparent. Considered in terms of the opening quotation from The Human Condition above, the law thus conceived must be assumed to be "entirely ... public" and therefore shallow, as no one less than Rawls seems to recognise. ${ }^{3}$ Section VI (Literary Depths and the "Shallowness" of Law) nevertheless goes on to argue that the law is not shallow. The apparent shallowness of the law concerns, in fact, the inverse or negative depth of the law. The inverse depth of the law consists in the way it deliberately takes leave of or withdraws from the existential depths explored in literature. Law and politics are not and should not be concerned with compassion, but literature is and can be so at heart's desire, Arendt contends.

Section VI reads this distinction between literature and politics as an invitation to explore a relation between law, politics and literature that takes leave of the edifying view of this relationship currently on offer in "law and literature" circles in terms of which law can gain insights from literature. The different understanding of the relation between law and literature that comes to the fore in Arendt's thought illuminates the directly opposite trajectories of appearance evident in literature, on the one hand, and law, on the other. Law and literature traverse the same space of appearance, but they do so in directly opposite directions. These inverse trajectories of law and literature do not render the one profound and the other shallow. They render the one positively and the other negatively profound. At issue here is not the shallowness of law when compared to literature, but the inverse or negative depth of law.

Section VII (The Inverse or Negative Depth of the Law) illuminates the legal theoretical gains evident in the Arendtian regard for the negative or inverse depth of the law. It shows how this understanding of the law helps us to come to terms with the legal theoretical and doctrinal puzzles that Arendt raises in response to the Eichmann trial. Section VIII (Back to the Beginning) briefly returns to reflect on the passage from The Human Condition with which we began in view of the thoughts expounded in its wake.

\section{APPEARANCE, REALITY, TRUTH}

\footnotetext{
${ }^{3}$ John Rawls Political Liberalism (New York, Columbia University Press, 1996) 243.
} 
A number of key passages in On Revolution show how much Arendt's political thought pivoted on key concerns of phenomenology. Close to the beginning of the work she makes an almost programmatic enunciation in this regard:

"For political thought can only follow the articulations of the political phenomena themselves, it remains bound to what appears in the domain of human affairs; and these appearances, in contradistinction to physical matters, need speech and articulation, that is, something which transcends mere physical visibility as well as sheer audibility, in order to be manifest at all."4

At issue in this passage is not only the phenomenological concern with phenomena, but more specifically the hermeneutic turn in phenomenology that Heidegger would bring about in Sein und Zeit. ${ }^{5}$ Phenomenology would henceforth turn increasingly to linguistic disclosure and less to empirical observation (mere visibility/sheer audibility) as the source of appearing and appearance in human concerns. Appearing or appearance, phainesthai, would become a matter of coming to language or being on the way to language, as the title and thrust of one of Heidegger's later works suggest. ${ }^{6}$

What the phenomenologists, hermeneutic or epistemological, had in common was the conviction that truth, Being or reality was not a fixed object beyond the empirical observations or interpretive understanding of the subject, but only and exactly that which comes to the fore in the intentional observation or understanding of the subject. Arendt undoubtedly shared this frame of mind and she invoked it in poignant fashion to analyse the cause of the interminable suspicions that informed Robespierre's "terror of virtue" during the French Revolution. As she put it:

"Theoretically, the answers to these questions may ultimately lie within the range of one of the oldest metaphysical problems in our tradition, the problem of the relationship between being and appearance, whose implications and perplexities with respect to political realm have been manifest and caused reflection at least from Socrates to Machiavelli. The core of the problem can be stated briefly and, for our purpose, exhaustively by recalling the two diametrically opposed positions which we connect with these two thinkers.",

For Socrates, contends Arendt, appearance is the truth in human affairs. There is nothing behind appearance which politics can or ought to pursue. Machiavelli's thought, in clear contrast, is informed by the assumption of transcendent Being, the assumption of a transcendent reality beyond the worldly realm of mere appearance. For Machiavelli, the latter is all that counts in politics. The Christian doctrine of two worlds, the heavenly and earthly, thus released the earthly from the constraints of truth and freed it up for the strategic pursuit and maintenance of secular power. This Christian understanding did not make truth irrelevant for politics. As Arendt, points out, Machiavelli was as concerned as Socrates with "hidden crimes", but for him such crimes were known and punished by God, not by men. The acts of the sovereign rulers were therefore not to be judged on earth. ${ }^{8}$ Socrates, argues Arendt, believed in the inevitability of the disclosure of truth in politics. For him, the truth of politics could not but appear. This was so because the political actor already and inevitably

\footnotetext{
${ }^{4}$ Arendt On Revolution (New York, Penguin Books, 1990) 19.

${ }^{5}$ Martin Heidegger Sein und Zeit (Tübingen, Max Niemeyer Verlag, 1979$) 37$.

${ }^{6}$ Heidegger Unterwegs zur Sprache (Pfullingen, Günther Neske 1986).

${ }^{7}$ Arendt On Revolution 101.

${ }^{8}$ Arendt On Revolution 101-102.
} 
appears to himself. There was an internal division in the political self between "the agent and onlooker". In order to deceive others, the agent also had to deceive himself. That is why, contends Arendt, the Greek polis necessarily was a world of phainomena, of true appearances:

"[T]he polis, and the whole of the political realm, was a man-made space of appearances where human deeds and words were exposed to the public that testified to their reality and judged their worthiness. In this sphere, treachery and deceit and lying were possible, as though men, instead of 'appearing' and exposing themselves, created phantoms and apparitions with which to fool others; these self-made illusions only covered up the true phenomena (the true appearances or phainomena), just as an optical illusion might spread over the object, as it were, and prevent it from appearing.",9

Arendt's argument is ultimately that deception was a hard feat to pull off in this world so intent on letting the truth come out, on letting it appear. It was "too ambitious", she says, for in order to deceive others effectively, the agent first had to deceive himself, his inner onlooker, just as we still say today that an actor must make a role his own to make his acting convincing to others. ${ }^{10}$ Her argument is compelling to the extent that it surely must have been more difficult to deceive in the close-knit political community of the Greek polis where public scrutiny was a matter of daily routine, than it is in the endless bureaucratic corridors of power of modern societies. It must surely have been much more difficult to constantly and coherently maintain a facade in which the actor did and could not believe himself, in the former, than it is in the latter. But the argument surely cannot claim to deal comprehensively or conclusively with the problem of treachery and deception. It does not deal with the fact that pathological deception - the hidden crime - remains a problem which the phenomenological concern with appearance, in the whole phenomenological tradition, has yet to/will always have to come to terms. Was the Greek polis really so innocent, so thoroughly candid, so thoroughly disclosing, so thoroughly phenomenological, one might say, as to render "the phenomenon of deception" an insignificant question? Arendt and the phenomenological tradition would seem to assume the fundamental innocence of appearance. For them "the phenomenon of deception" would seem to be an oxymoron that need not detain us for long. This is the weak side of her argument, and the weak point that must always haunt the phenomenological tradition. It is a weak point, however, that will and must also continue to haunt earthly existence as such. It can only be overcome, rendered a non-problem, by the religious assumption of an omniscient God that really knows the hearts of men and will ultimately punish the wicked. It is only realistic to assume that many hidden crimes and treacheries have indeed gone down in history completely undetected; hence perhaps the ultimate allure of faith, religion and God.

Phenomenology cannot play God. It accepts the irreducibly and irredeemably finite and perspectival nature of human cognition. But it can claim confidently enough that the inescapable and vast variety of perspectives among humans, conditioned as it is by the irreducible plurality of human existence, afford humans at least provisionally reliable cognitions of epistemological and political essentials - that which everyone from their varying perspectives can consider as incircumventible perspectives and therefore incircumventible "truths" of human co-existence. These essentials never attain to the conclusive stability of Platonic ideas, but the loss of this Platonic

\footnotetext{
${ }^{9}$ Arendt On Revolution 103.

${ }^{10}$ Arendt On Revolution 103.
} 
certainty also rids cognition of the equally Platonic idea of a false world of mere opinions, as Arendt noted well with reference to Nietzsche famous observation in this regard: "We have abolished the true world. What has remained? The apparent one perhaps? Oh no! With the true world we have also abolished the apparent one". ${ }^{11}$ Once rid of the impulse to purchase the burdensome insurance policy of absolute truth, humans may regain the simple experience of the world, the simple experience of the "there is" of the world, as Merleau-Ponty wrote. ${ }^{12}$ Phenomenology clearly anticipated the Rawlsian insight that public reason offers us a common world even though and exactly because it does not seek to offer us the ultimate truth of things. ${ }^{13}$ I shall return to this point below.

Arendt makes her point regarding the political and phenomenological truth of the world of appearance against the background of the French Revolution and Robespierre's "terror of virtue". If there is a lesson to be learnt from Robespierre's "terror of virtue", she maintains, it is this: An undue concern with truth and truthfulness in politics cannot avoid becoming murderous and cannot hope to create and maintain anything like a lasting and stable polity. For there is no way that the best of human hearts can prove itself to be fully virtuous; there is no way that any political institution can claim to reflect the full truth of human existence. If politics is to pursue perfect virtue and conclusive truth, it must turn into the constant elimination of suspected vice and the constant destruction of ever-imperfect institutions. Thus did the French Revolution come to devour its children and failed to produce lasting legal institutions. The American revolution was relatively bloodless and produced a lasting polity with a lasting constitution exactly because the American founders made peace with the vice of men and believed it could be contained adequately enough through political participation and the varying perspectives afforded by the free competition of multiple opinions. As Arendt puts it, "their common sense was never exposed to the absurd hope that man, whom Christianity had held to be sinful and corrupt in its nature, might still be revealed to be an angel". ${ }^{14}$ Phrased in phenomenological terms one can say they trusted that an on-going exchange of admittedly finite perspectives would safeguard the minimum levels of essential knowledge and essential virtues required for durable human co-existence, notwithstanding the possibility, likelihood or inevitability of less than virtuous and less than truthful perspectives also taking part in these exchanges.

The times through which Arendt lived would not spare her an awareness of vicious political crimes and radical evil in politics. She was duly conscious that such crimes and evil can also "make their appearance". "[W]herever they make their appearance," she observed, "they transcend" and "radically destroy" the "realm of human affairs and the potentialities of human power". ${ }^{15}$ She can perhaps be read to have phrased this view more rigorously when she earlier contended that the power of totalitarian movements consisted exactly in not appearing, that is, in not showing or revealing

\footnotetext{
${ }^{11}$ Arendt The Life of the Mind (New York/London, Harcourt Inc, 1978) 11.

${ }^{12}$ Arendt The Life of the Mind 49: "What Merleau-Ponty had to say against Descartes is brilliantly right: 'To reduce perception to the thought of perceiving . . . is to take out an insurance against doubt whose premiums are more onerous than the loss for which it is to indemnify us: for it is to . . move to a type of certitude that will never restore to us the "there is" of the world."

${ }^{13}$ Rawls Political Liberalism 212-254 (the lecture on Public Reason).

${ }^{14}$ Arendt On Revolution 95.

${ }^{15}$ Arendt The Human Condition 241.
} 
itself, in remaining secret and secretive, in consistently avoiding any recognisable shape. ${ }^{16}$ The latter position is more consistent with the phenomenological politics that we are distilling from her work in this essay; more consistent with her own analysis of deception as non-appearance or an obstruction of appearance. Totalitarian movements are indeed fundamentally "anti-phenomenological" in the way they destroy the interaction and inter-interrogation of multiple political perspectives; in the way they refuse contestation. They reduce the human condition of plurality to a oneness that monopolises interrogation murderously, if not indeed to a oneness achieved through murder; a oneness by murder that neither bothers nor needs to interrogate, but simply annihilates otherness. ${ }^{17}$ Claude Lefort, life-long friend of Merleau-Ponty and editor of L'Visible et l'invisible may well have taken much inspiration also from this work when he later defined totalitarianism in terms of its suppression of plurality and fundamental assumption of the oneness of the people. ${ }^{18}$ The most consistent way of describing such totalitarian destructions of plurality phenomenologically would be to invoke, not the appearance of some or other pathological variety of the political, but the complete dis-appearance of the political as such. The Arendtian concern with the appearance of the political must therefore endorse a constant multiplicity of political opinions and factions. ${ }^{19}$ Her concerns with appearance and plurality go hand in hand.

Be it as it may, Arendt did not entertain the notion of the innocence of "normal" or "healthy" democratic politics, the innocence of appearance. Getting rid of the burdensome insurance policy of absolute truth was not, according to her, going to eliminate the risk of serious political harm that may well have spawned the quest for that policy in the first place. It may at best spare us the excess harm to which that policy itself often gave and gives rise. Arendt was well aware that the finite perspectives that inform all political action invariably doom politics to cause unforeseen harm, however much it may have been contemplated and executed in good faith; hence her regard for the crucial role of forgiveness in human politics. Nothing new would ever appear in the world without forgiveness, for no new action can ever be taken again without an act of forgiveness:

"Without being forgiven, released from the consequences of what we have done, our capacity to act would, as it were, be confined to one single deed from which we could never recover; we would remain the victims of its consequences forever....,20

One could tie up this thought by contending that appearance requires forgiveness; forgiveness conditions appearance. There is thus an intrinsic relation between appearance, forgiveness and giving. A certain civility and generosity sustain the world and the possibility of new worlds. ${ }^{21}$ Appearance gives and for-gives the world.

\section{APPEARING: THE PHAINESTHAI OF THE PHENOMENON}

\footnotetext{
${ }^{16}$ Arendt The Origins of Totalitarianism (New York/London, Harcourt Inc, 1976) 403.

${ }^{17}$ Cf. Arendt Eichman in Jerusalem (New York, Penguin Books, 1994).

${ }^{18} \mathrm{Cf}$. Lefort's analysis of the logic of totalitariniasm in terms of "du peuple-Un" and "d'un pouvoirUn" that allows for no differentiation. Cf. Lefort L'invention démocratique (Paris, Fayard, 1994) 101.

${ }^{19}$ Arendt On Revolution 93, 225.

${ }^{20}$ Arendt The Human Condition 237.

${ }^{21}$ For an insightful comparison between Arendt and Nietzsche on this count, cf. Marinus Schoeman Generositeit en Lewenskuns (Pretoria, Fragmente Uitgewers, 2004).
} 
Appearance nevertheless does not always give us our daily bread, as the pervasive appearance of poverty makes all too clear. Arendt was remarkably cavalier about this, as we shall soon see. But appearance does give us whatever existence we have. It does so by way of an emergence, an event of disclosure that draws or redraws the line between the disclosed and the undisclosed, the visible and the invisible, the known and the unknown, the comprehensible and the incomprehensible. Natural human consciousness, a pervasive aspect of the human condition, consists in an act of overlooking that allows for intentional vision or sight. Within the window of vision opened by this act of overlooking, modern science and epistemology constructed a paradigm of knowledge that pivoted on a subject-object relationship and the endeavour to ensure the subject mirrors the object adequately if not perfectly. But the windows of vision that open by acts of overlooking precede the subject-object oriented paradigms of science. The subject-object paradigm of science comes later. It articulates itself within a space already opened by the fundamental act and fact of human intentionality, already opened by the window of intentional looking and overlooking.

Science is thus already far removed from the human being's initial encounter with the world. It is far removed from the way things appear to humans, far removed from the thing itself, die Sache selbst. This was Husserl's opening gambit with which he launched a mode of philosophical inquiry that would first become known as phenomenology, as he himself called it, then as hermeneutics, due to Heidegger's intervention, and still later as deconstruction, as Derrida would have it. Zurück zu den Sachen selbst (back to the things themselves) was Husserl's call in response to his perception that modern science was increasing losing touch with human existence, that is, with the lived world or life-world of humans. ${ }^{22}$

The phenomenological return to the things themselves concerns an engagement with the dark margins of intentional consciousness that continue to haunt and circumscribe enlightened or illuminated intentionality. These margins require phenomenology to retrace its own steps again and again so as to capture or recapture that which has again eluded and will ever again have eluded intentionality. This is the point of Husserl's obsessive phenomenological reductions. Husserlian phenomenology, argues Maurice Merleau-Ponty, thus became a Sisyphean concern of consciousness with its own constituting boundaries, with that which always remains overlooked so as to constitute intention. Martin Heidegger would emphasise in comparable regard the irreducible lethe that marks the aletheia or aletheuein of phainesthai, the sombre concealment from which the disclosure at issue in any coming to light cannot extract itself. These Husserlian and Heideggerian themes are clearly evident in the passage from The Human Condition with which we began.

The method through which phenomenology seeks to return to the things themselves so as to capture their essence are ever-incomplete and interminable, contends Merleau-Ponty. Phenomenology seeks to say what remains unsaid, it is an eternal recommencement - [l] e philosophie dit encore les inédits, est un commencant perpetuel. ${ }^{23}$ Husserl's transcendental consciousness, claims Merleau-Ponty, was not

\footnotetext{
${ }^{22}$ Cf. Husserl, E Die Krisis der europäischen Wissenschaften und die transzendentale Phänomenologie, Husserliana Bd XXIX (Dordrecht/Boston/London, Kluwer Academic Publishers, 1993) 167-245.

${ }^{23}$ Maurice Merleau-Ponty Phénoménologie de la Perception (Paris, Gallimard, 1945) 14.
} 
Kant's time-proof transcendental set of categories and forms of perception, but a historically contingent and precarious undertaking that had to retrace its own steps continuously. In his own work Merleau-Ponty invokes the notion of a bodily existence that precipitates a now errant, now re-assembled visibility - la visibilité tantôt errante et tantôt rassemblée. ${ }^{24}$ And this incessant errancy and recommencement, Merleau-Ponty points out, phenomenology shares with literature and art. He also invokes in this regard a thought that is central to Arendt's work, namely, the natality of history, l'histoire à l'état naissant. ${ }^{25}$ Arendt can nevertheless be said to have added something unique to this regard for the natality of history that is crucial for her understanding of law and literature and the difference between them. It is tempting to say that she exempted law from the exploratory phenomenology of literature and art that Merleau-Ponty points out here. But this would not be the full story, as we shall soon see. Law indeed comes forth from the nascent state of things by taking leave of literature, by splitting off from it. As will become clear below, the birth of both law and literature consists for her in them splitting up and veering off into different and quite opposite directions. This is a crucial move in her thinking that guides one towards a profound phenomenology of law, that is, to a profound understanding of the way the law first appears in the world.

On the basis of this phenomenology of law, resolutions of some of the oldest conundrums in legal theory - notably those that came to the fore in the Eichmann case - suddenly become plainly visible, as we shall see below. But the splitting off that takes place between law and literature does not mean that they no longer share the space of appearance. They continue to do so, but they do so differently. An incisive phenomenology of law must mark both its abyssal difference from and its intimate proximity to literature and art. The law is fundamentally different from art and literature and does not tolerate facile translations of literature into law, as Richard Posner notes well, ${ }^{26}$ but it remains close to literature because of the way it shares with literature the same space of appearance.

Legal theory's prolonged struggles with the conundrums in the Eichmann case may well relate to the fact that it has all along been addressing them from too far, that is, from within the confines of a positivist legal scientific discourse that is already miles away from the way the law appears in the world, miles away from the things at issue when the law first appears. Arendt's phenomenology of law casts light on these conundrums by affording legal theory a return to the fundamental thing that takes place when we begin to call something law, that is, by affording legal theory a return to the thing [of law] itself. But in the same move that would come to cast so much light on the law, she would also allow a shadow to fall over her work. We need to retrace our steps and address this shadow over her work, this blind spot in her phenomenology of law.

\section{HER SHADOW AND ITS SHADE}

\footnotetext{
${ }^{24}$ Merleau-Ponty Le visible et l'invisible (Paris, Gallimard, 1964) 181.

${ }^{25}$ Merleau-Ponty Phénoménologie de la Perception 22.

${ }^{26}$ R Posner Law and Literature (Cambridge, Massachusetts/London, England, Harvard University Press, 1998) 324-332. For a further discussion of Posner's views in this regard, cf. Van der Walt “Agaat's Law - Reflections on Law and Literature with Reference to Marlene van Niekerk's Novel Agaat" (2009) 126 South African Law Journal 695, 699.
} 
Arendt's diagnosis of the Jacobin terror in On Revolution highlights the spurious link it effected between politics and compassion, and more specifically, the link between politics and the compassion with the poor. ${ }^{27}$ The diagnosis is, on the one hand, informed by a strong and accurate intuition regarding the need to sever politics from passion of whatever kind, compassion included. It is nevertheless also deeply misguided in the way it appears to equate or at least conflate the self-evidently legitimate rational political concern with poverty, on the one hand, and compassion with poverty, on the other. A critical engagement with Arendt's thought on this count must show up her failure to distinguish clearly and more thematically between the rational political concern with poverty and compassion with poverty. Her contention that poverty is not a political concern is scandalous, as I have averred above, because of the way it nostalgically reduces the political to a romantic, nostalgic and misguided concern with pure political freedom as such, as if politics, like art, is nothing but a concern with creative freedom and the pursuit of excellence, and not more fundamentally a concern with the freedom to establish the most reasonable and enduring forms of communal life that circumstances would allow.

Poverty is not just a question with regard to which some of us personally are as passionate or compassionate as others are dispassionate or compassionless (as the average Democrat/Republican or Labour/Tory split might prompt one to conclude). It is a concern which everyone could and should rationally acknowledge as central to the broader political concern with stable and enduring polities. It was in the wake of a fatal dis-appearance of the political that the writers of the German Grundgesetz of 1949 insisted that the Federal Republic of Germany would henceforth be a social state. Never again, was the idea and aspiration, would masses of disempowered and desperate people become the essential energy of totalitarian imaginations. The social state clause - art 20(1) - in the German Grundgesetz is an embodiment of the insight that a critical minimum of social politics is a precondition for sustaining the appearance of the political.

The political concern with founding and maintaining stable polities surely allows for and requires a good deal of creativity and imagination, but it is not principally or purposefully concerned with this creativity. Arendt's mistake was to turn one of the conditions for and means of politics - creative imagination - into its end. Thus does she end up with an understanding of politics as political theatre that is scandalously out of touch with the exigencies and democratic consciousness of her time and smacks more of the politics of grandeur of pre- and post-revolutionary Europe, feudal and restoration-era Europe, than the revolutionary spirit that she claims to celebrate. As such her political thought was remarkably out of touch with the appearance of her own time, that is, with the way human concerns showed themselves in the time she lived. She was clearly out of touch with the fundamental phenomenological awareness of how different historical times demand different responses and responsibilities from humans - indeed creative and imaginative responses and responsibilities. Arendt would not accept that the social question had become a major political concern in the wake of the great transformation of society wrought by modern capitalism. She was aware of this transformation. That the poor had "appeared" irrevocably on the political scene of modernity, was something she knew and sometimes articulated in

\footnotetext{
${ }^{27}$ Arendt On Revolution 59 - 114.
} 
inimitable fashion. Referring to the multitude on the march during the French Revolution, she wrote:

"[T] his multitude, appearing for the first time in broad daylight, was actually the multitude of the poor and the downtrodden, who every century before had hidden in darkness and shame. What from then on has been irrevocable, and what the agents and spectators of revolution immediately recognized as such, was that the public realm - reserved, as far as memory could reach, to those who were free, namely carefree of all the worries that are connected with life's necessity, with bodily needs - should offer its space and its light to this immense majority who are not free because they are driven by daily needs." 28

Arendt's work is fundamentally informed by this observation. It is driven by it. Her work is driven by the regretful perception that the appearance of poverty on the stage of politics ruined this stage. Her regret in this regard stemmed from a wilfully romanticising and deeply melancholic interpretation of ancient Aegean politics. Her romanticism and melancholy - and its almost obsessive fascination with excellence committed her to a political position that can easily confused if not compellingly associated with the passionate lack of compassion that progressive political thought associates today with the libertarian right. That the same thought appears differently in different times was not one of her eminent concerns. ${ }^{29}$

This is the shadow that hangs over her work, one that may well relate in complex ways to a larger shadow that cast a whole generation of especially German but also broader European politics into darkness. ${ }^{30}$ But shadows do cast shades and in the shadow of Arendt's thought also looms a crucial insight under which contemporary political thought may yet find shelter against the allure of darker nights. At issue here are her reflections on the source of darkness in politics, namely, the darkness of the human heart. In a passage that resonates deeply with our opening quotation above, she writes:

\begin{abstract}
"Whatever the passions and the emotions may be, and whatever their true connection with thought and reason, they certainly are located in the human heart. And not only is the human heart a place of darkness which, with certainty, no human eye can penetrate; the qualities of the heart need darkness and protection against the light of the public to grow and to remain what they are meant to be, innermost motives which are not for public display. However deeply heartfelt a motive may be, once it is brought out and exposed for public inspection it becomes an object of suspicion rather than insight; when the light of the public falls upon it, it appears and even shines, but, unlike deeds and words which are meant to appear, whose very existence hinges on appearance, the motives behind such deed and words are destroyed in their essence through appearance; when they appear they become "mere appearances' behind which again other, ulterior motives may lurk, such as hypocrisy and deceit."
\end{abstract}

This then was the unforgiving logic that doomed Robespierre and the Jacobins, once committed to a politics of the heart and heart-felt compassion, to interminable

\footnotetext{
${ }^{28}$ Arendt On Revolution 48, emphasis added.

${ }^{29}$ Arendt famously explained Heidegger's involvement with the National Socialist Party in terms of the political idiocy typical of philosophers like Thales, who, with their gaze fixed in wonderment on the stars, stumble into holes. Cf. Arendt and Heidegger Hannah Arendt Martin Heidegger Briefe $1925-$ $1975179-192$. Her failure to respond to something so central to the politics of her own time surely smacks of the same political idiocy. Fixated on the "purely political nature" of the first American Revolution of 1776, she appeared to be completely oblivious to the second American Revolution, the New Deal Revolution of 1937, literally in the wake of which she was writing and of which poverty and social equality were the exclusive concerns.

${ }^{30}$ Compare Derrrida Of Spirit. Heidegger and the Question (Chicago, University of Chicago Press, 1987) 109

${ }^{31}$ Arendt On Revolution 96.
} 
suspicions regarding the pureness of their hearts. ${ }^{32}$ If the secrets of the heart are to be fathomed in human affairs, contends Arendt, it is not in politics that this should be done, but in poetry and literature:

"If we want to know what absolute goodness would signify for the course of human affairs (as distinguished from the course of divine matters), we had better turn to the poets, and we can do it safely enough as long as we remember that 'the poet but embodies in verse those exaltations of sentiment that a nature like Nelson's, the opportunity being given, vitalizes into acts' (Melville). At least we can learn from them that absolute goodness is hardly any less dangerous than absolute evil...., 33

The crucial move that Arendt makes here is to extract the exultations of sentiment from the concerns of politics and to reserve them for the domains of literature. Exultations being exultations do not come in half measures. They are absolute and for this reason not fit for translation into politics. They are as dangerous for the political when they are good as they are when they are bad; hence the need to separate politics from sentiment and the secrets of the heart, that is, from the dark concerns of life. She confines the former to the demanding light of reason. The latter she reserves for literary explorations that not only render them safe to explore ("we can do it safely enough"), but also guard them safely. Following a suggestion of Italo Calvino, one can say that Arendt recognises the apocryphal origins and nature of literature, its emanation from (apo) the secret (kryphos). ${ }^{34}$

The significance of this move - this separation of politics from life - becomes clear when one brings to bear on Arendt's thought Giorgio Agamben's engagement with the relation between life and politics and life and law. Central to Agamben's thoughts in this regard is the endeavour to stabilise the distinction between the state of exception and the regular rule of law. His earlier work Homo Sacer already announced the need for an alternative to the politics of the ban and the constant risk of totalitarian slippages between states of exception and the regular rule of law that this politics always run (slippages during which the state of exception becomes the rule and auctoritas and potestas become one). In his recent work on St Paul he finally finds this alternative in the notion of messianic time of the Christian ekklesia. The Christian community lives under the rule of earthly law as if not (hos me) living under it, as if living already now under the reign of the Messiah and the final redemption by and reckoning of God. ${ }^{35}$ The real state of exception, the realisation of the full potentiality of existence, is thus postponed to the day of final reckoning to which God has the sole prerogative.

At issue in this Christian thought is indeed the prerogative of God to unite auctoritas and potestas and life and law. God alone can make law that redeems life. The only redemption possible in the meantime, suggests Agamben, is the literary redemption offered by literature. The task of literature, he contends with reference to Dostoyevsky, is to remember unforgettable life, to remember unredeemed singular life, to remember the secrets of the heart, we can say with reference to Arendt. Literature is thus to effect some measure of the redemption for which earthly politics

\footnotetext{
${ }^{32}$ ibid.

33 ibid at 81.

${ }^{34} \mathrm{Cf}$. Calvino If on a winter's night a traveller (London, Vintage Paper Back, 1988) 72; Van der Walt

"Agaat's Law" 713.

${ }^{35}$ Giorgio Agamben The Time that Remains (Standford, Stanford University Press, 2005) 19-26.
} 
is not destined. ${ }^{36}$ A similar delegation of redemption and the state of exception to the domain of literature is evident in Arendt's thinking. By reserving the dark secrets of the human heart for literary explorations, she confines it to a domain beyond the regular rule of law and prevents it from contaminating the law with apocalyptic visions. Literature, we shall see, constitutes the only real state of exception in her thought.

\section{THE LITERARY EXCEPTION}

Does Arendt really reserve the state of exception for literature? Is she not the one who, with reference to Jefferson, endorsed every generation's right to rebel? ${ }^{37}$

Not quite, or in any case, not simplistically so. Her ultimate concern was surely the ability of political action to found lasting political institutions, institutions moreover, that are founded on pre-existing principles of positive or at least natural law that are not the product of revolutionary creation. Revolutions, she maintained, are acts of "restoration and re-establishment". ${ }^{38}$ In this regard, she can be said to have been concerned, like Agamben, with the stabilisation of the distinction between constituent and constituted power and between potentiality and actuality. With regard to both these pairs of concepts, her concern clearly prioritised the latter over the former. For Arendt, the primary task of revolutions can ultimately only be to re-enact the eternal and unchangeable principles of natural law. Revolutions do not create or bring to the fore new principles of justice, they rely on and re-enact the ever present and already disclosed principles of natural law, "the laws of nature and nature's God", "truths" that could be held as "self-evident". ${ }^{39}$ In this regard Arendt's thought appears to erase the concern with states of exception from her contemplation of worldly politics. She seems to remove the sovereign and the state of exception from the scene of revolution. The fundamental principles of law are always in place. Revolutions do not challenge them, they rely on them. If there remains an element of a real state of exception in her thought, a real sovereign encounter with bare life, it is the literary state of exception. It is for literature that she reserves the exploration of the secrets of the heart and of life and the ultimate concerns of life with questions of good and evil.

In this regard Arendt also seems to have exempted the fundamental principles of law from the trajectory of appearance outlined in the passage from The Human Condition with which we opened our inquiry into her thought at the beginning of this essay. The law does ultimately not emanate from some dark private mystery so as to appear in the broad daylight of the public. The law is for her that aspect of public life that is always already and therefore exclusively public. It does not come forth from the darkness of the private into the light of the public. Or so it seems. And this leaves us with the question whether the law, like a life spent entirely in public, is shallow. Does Arendt ultimately leave us with a concept of law that is necessarily shallow, especially when compared with the depths explored by literature? If so, she is surely not the only prominent thinker of our time to have done so. John Rawls also argued

\footnotetext{
${ }^{36}$ For a more extensive discussion of Agamben on this point cf. Van der Walt "The Shadow and its Shade" 2009 South African Public Law 269-296; Van der Walt Law and Sacrifice (London, Cavendish, 2005) 197-204.

${ }_{37}$ Arendt On Revolution 232-233.

${ }^{38}$ ibid at $208-211$.

${ }^{39}$ ibid at $192-193$.
} 
for fundamental principles of law that would exclude from their scope comprehensive convictions regarding good and evil and the deeper concerns of the heart. He referred to the principles of public reason in this regard and expressly acknowledged their apparent shallowness:

\footnotetext{
"As institutions and laws are always imperfect, we may view that form of discourse as imperfect and in any case as falling short of the whole truth set out by our comprehensive doctrine. Also, that discourse can seem shallow because it does not set out the most basic grounds on which we believe our view rests." 40
}

\section{LITERARY DEPTHS AND THE “SHALLOWNESS” OF LAW}

Prominent conceptions of the relationship between law and literature current today understand the private/public divide in terms of a facile trajectory of private truths from the dark secrets of the heart into the daylight of law, into the daylight of the public. The literary regard for the secrets of the heart improves the law. It teaches the law mercy. Thus can the law - literary informed law - increasingly accommodate the private in the public sphere. ${ }^{41}$ The phenomenological experience of the private/public divide evident in Arendt's work contradicts and rejects these conceptions of law and literature fundamentally. At issue in them is a metaphorical understanding of the relation between law and literature in terms of which the insights of the former can simply be carried over (meta-pherein) from literature to law. Thus does literature become a source of useful metaphors for legal reasoning. This understanding of law and literature cannot but leave both doomed to shallowness.

The phenomenological understanding of the relation between law and literature, to the contrary, experiences invariably how literature and law split off into different directions, the one into the direction of the dark, unique, intimate, uncommunicative and incommunicable secrets of the human heart, the other into the need for transparency and rules of common understanding. Borrowing from Heidegger, one can call this experience of an originary splitting between literature and law diaphorical. Central to this experience is the observation of an event of splitting that carries human experience off into two different or differing (dia-pherein) trajectories. ${ }^{42}$ With Merleau-Ponty, one can call this a chiasmic experience of the relation between of law and literature. ${ }^{43}$ It is an experience that invariably sees literature veering off into the invisible and the obscure, law into the visible and the transparent. This is how the law appears. It appears by withdrawing from all literary concerns with the secrets of human heart. Thus does it attain a quality of having appeared; of having emerged from the dark secrets of the private and the heart, if only by having taken leave of them. Thus does it attain a unique depth.

Law and literature come to the fore from the same event, from the same diaphoric or chiasmic splitting (Zwiefalt) that sends them off into different directions. Having event-ually, that is, through the event of their splitting, become literature, on the one hand, and law on the other, they relate differently to this originating event. Literature, especially poetry, incessantly and obsessively harks back to its origin, that is, to the

\footnotetext{
${ }^{40}$ Rawls, Political Liberalism 243.

${ }^{41}$ For a critical engagement with this understanding of law and literature, cf. again Van der Walt

“Agaat's law" 695-739.

${ }^{42}$ Heidegger Unterwegs zur Sprache 25.

${ }^{43}$ Merleau-Ponty Le visible et l'invisible 172-204, 268-270.
} 
event from which it originates. In order to do so it cannot but risk the obscurity of its origin and therefore must claim for itself the exceptional sovereignty and licence to risk this obscurity. The law, on the other hand, by definition forfeits this licence and sovereignty. The law is by definition that which must come clear, that which must take leave of its origins in order to become clear, in order to become transparent enough to establish common rules of mutual understanding and civility.

The law's forfeiture of sovereignty nevertheless does not happen instantaneously and never happens conclusively. This is the profound insight that Kelsen articulates when he states that pure law never exists. Pure law, the law contemplated by a pure theory of law, is never positive or posited - nie gesetzt. Pure law is always only presupposed (vorausgesetzt) by a pure theory of law. ${ }^{44}$ The reality of law always retains the imprint of its sociological and existential origins. It never sheds the shadows of the shades whence it commenced. To be sure, it by definition resists these shadows. Its negative or negating relation to its origins defines it. But the very definitional nature of this negation and resistance means the negated and resisted origin cannot be erased. Law cannot shed its shadow. The shadow cannot be shed. The law, too, is irreducibly apocryphal. $^{45}$

The law does therefore appear, does come forth from darkness, is therefore not shallow but profound for the very reason of its on-going denial of depth, for the very reason of its insistence to move towards the light and become fully illuminated, fully transparent and therefore apparently shallow. The law is as profound as literature, only differently so, negatively or inversely so. Those who do not sense this unique depth behind Rawls' acknowledgment of the shallowness of law and public reason fail to do so for reasons of lacking an essential phenomenological consciousness. Those who fail to sense the depth in Arendt's paradoxical concern with a revolutionary natality that is "sheltered by the transparent virtues with which our ancestors have at least sometimes set the world at peace", 46 do so for reasons of failing or refusing to observe how things have come and still come to appear to humans. Human reality shows itself by the way law and literature (and art) split off into opposite directions and contrasting relations to their common origins.

Arendt sometimes leaves one with the impression that the law does not appear. Lawmaking, she writes in The Human Condition, was not considered by the ancients to be action in the political sense of the word and thus did not figure within the "space of appearance". Law-making was a form of manufacturing, the work of homo faber. Homo faber, she argues, only appeared by virtue of his artefacts and this appearance was inferior to political action through which the actor appeared by showing himself. ${ }^{47}$ The ancients likened the work of law-making to the building of the city walls, that is, to work that had to be done and finished "before political action could begin." "48 The conception of constitution-making that she expounds in On Revolution differs radically from the view of law-making expounded in The Human Condition.

\footnotetext{
${ }^{44}$ Hans Kelsen Reine Rechtslehre. Einleitung in die rechtswissenschaftlcihe Problematik (Leipzig, Deuticke, 1934) 66-67.

${ }^{45}$ Cf. Van der Walt "Agaat's law" 739. The law, too, is apocryphal, I argued already here, but it is so "in a state of denial", that is, negatively so.

${ }^{46}$ Arendt On Revolution 211.

47 Arendt The Human Condition 207-212.

48 ibid at 194 .
} 
Had she left matters with "the laws of nature and nature's God", and with John Adams' "great Legislator of the Universe", ${ }^{49}$ she surely would have been stuck in an understanding of law-making as an activity that precedes politics and is already accomplished before political action commences. She would have been stuck in a conception of law as a pre-existing and eternal presence that is always already selfevident and requires no appearance, no disclosure. Her phenomenological background, however, would not have allowed her to tolerate this metaphysics of presence, a metaphysics which here makes particularly clear its onto-theological trappings, ${ }^{50}$ its assumption of a "great Legislator of the Universe" whose eternal laws underpin and secure the finite worlds of humans.

Arendt's first "destructive" or "deconstructive" step away from this metaphysics of eternal presence consisted in highlighting the incongruity evident in Jefferson's notion that constitutional provisions were "truths" that had to be held as "self-evident":

"Jefferson must have been dimly aware of [the fallacy of this position that ... mathematical 'laws' were of the same nature as the laws of a community, or that the former could somehow inspire the latter], for otherwise he would not have indulged in the somewhat incongruous phrase, 'We hold these truths to be self-evident', but would have said: These truths are self-evident...., 51

One clearly sees here - in this indispensible holding of truths as self-evident - an echo of the performative presupposition which Kelsen recognised as a condition for the notion of pure law, of law that is not just a matter of power, but authoritatively and self-evidently law and can therefore claim respect and obedience. Arendt highlights this performativity further by emphasising the promise or act of promising that informs this "holding as self-evident." And now, quite in contrast to The Human Condition she views this action to consist in world-building in the full political sense of the world. She no longer views it as the merely pre-political manufacturing of city walls:

"Hence binding and promising, combining and covenanting are the means by which power is kept in existence; where and when men succeed in keeping intact the power which sprang up between them during the course of any particular act or deed, they are already in the process of foundation, of constituting a stable worldly structure to house, as it were, their combined power of action. There is an element of world-building capacity of man in the human faculty of making and keeping promises. Just as promises and agreements deal with the future and provide stability in the ocean of future uncertainty where the unpredictable may break in from all sides, so the constituting, founding, and world-building capacities of man concern always not so much ourselves and our own time on earth as our 'successor' and 'posterities'.,"52

The law-making and constitution-making promise to hold as self-evident now not only qualifies as action. It qualifies, with reference to Cicero en plus as the most excellent form of political action:

"No man is so much raised on high by any of his acts as are those who have reformed republics and kingdoms with new laws and institutions....After those who have been gods, such men get the first praises." $" 53$

\footnotetext{
${ }^{49}$ Arendt On Revolution 185.

${ }^{50}$ Heidegger Einleitung zu Was ist Metaphysik in Heidegger Wegmarken (Frankfurt am Main, Vitttorio Klostermann, 1978) 373-374; Identität und Diferenz (Pfullingen, Günther Neske 1986) 50-51.

${ }^{51}$ Arendt On Revolution 193.

52 ibid 175 .

53 ibid 202.
} 
And what also becomes evident here - in this praise for the acts of founders and law makers - is the turn away from the worship of a Supreme Being to a worshipping of founding itself and a "blind worshipping" - in the words of Woodrow Wilson - of the constitution itself. This worshipping of the act of founding, argues Arendt, saved the American constitution from the crumbling of religious authority in the modern age: "[W]hat saved the American Revolution from this fate was neither 'nature's God' nor self-evident truth, but the fact of foundation itself". ${ }^{54}$ At issue here for Arendt is a thought that Heidegger pursued painstakingly in Der Satz vom Grund, namely, the notion of a ground or beginning that need not take its foundation from elsewhere, but carries it within itself. Heidegger invoked in this regard Angelus Silesius' rose that "exists because it exists"; it has its ground in itself and does not obtain it from elsewhere. ${ }^{55}$ Arendt turns to etymology. She invokes "the beginning and principle, principium and principle [that] are not only related to each other, but are coeval" as is suggested clearly by the Greek word arche which "means both beginning and principle". 56

The Heideggerian influence does not stop here, it only becomes more and more evident. The legends of founding, relates Arendt, "unanimously tell us of great leaders who appear on the stage of history precisely in [the] gaps of historical time":

"With respect to revolution, these tales ... insist on a hiatus between the end of the old order and the beginning of the new, whether it is of no great importance in this context whether the hiatus is being filled by the desolate aimless wanderings of Israeli tribes in the wilderness or by the adventures and dangers which befell Aeneas before he reached the Italian shore.... [T] his hiatus obviously creeps into all time speculations which deviate from the currently accepted notion of time as a continuous flow; it was therefore an almost natural object of human imagination and speculation, in so far as these touched the problem of beginning at all...,57

This passage evidently relies fundamentally on Heidegger's critique of linear conceptions of time. Heidegger articulated this critique for the sake of opening a different contemplation of time in terms of the event, the Ereignis. ${ }^{58}$ Heidegger understood the event in terms of a splitting, a Zwiefalt, a diaphorical opening of a rent or Riss. ${ }^{59}$ Merleau-Ponty would invoke in this regard le chiasme, la fission fondamentale. ${ }^{60}$ Le chiasme is the birth of history, or history in the state of its birth l'histoire à l'état naissant ${ }^{61}$; the earliest moment or not-yet moment in which the difference between the visible and invisible becomes manifest for and before the first time. Arendt' invocation of the hiatus clearly belongs to these phenomenological contemplations of the Ereignis and the chiasme. And it from the vantage point of this hiatus, Riss, Zwiefalt or chiasme that the significance of Arendt's thought for our understanding of law becomes clear. For it is crucial for our understanding of law to understand the arrival of the visible, the arrival of evidence and self-evidence, the arrival of law. We need to understand the nature and trajectory of this arrival.

\footnotetext{
54 ibid at 196.

${ }^{55}$ Heidegger Der Satz vom Grund (Pfullingen, Günther Neske, 1986) 101-102.

${ }^{56}$ Arendt On Revolution 212, 213.

${ }^{57}$ ibid at 205.

${ }^{58}$ Heidegger Sein und Zeit 372-437. Cf. also Zur Sache des Denkens (Tübingen, Max Niemeyer Verlag 1976) 1-25.

${ }^{59}$ Heidegger Unterwegs zur Sprache (Pfullingen, Günther Neske 1986) 24-33.

${ }^{60}$ Merleau-Ponty Le visible et l'invisible 172-204, 268-270.

${ }^{61}$ Merleau-Ponty Phénoménologie de la Perception 22.
} 


\section{THE INVERSE OR NEGATIVE DEPTH OF THE LAW ${ }^{62}$}

The law, then, is not shallow. It is brought forth by a profound commitment to hold certain truths as self-evident and transparent; self-evident or transparent to the extent of risking the appearance of shallowness. The law's profound commitment, we have seen, turns on two acts of giving: the act of promising and the act of forgiving. Perhaps we should begin to re-read the "civility" with which Rawls seeks to vault us past the apparent "shallowness of the law" in terms of this promise and forgiveness that Arendt brings to bear on legal and political thought. ${ }^{63}$

The law is as deep as literature, only inversely so. The law's depth is a negative depth. Unlike literature, it cannot affirm but must deny its own depth. It is nevertheless as deep and as apocryphal (a mere presupposition, not real, says Kelsen) as literature. This is so because they both come forth from the secret gaps in time for which historiography cannot account - the counter-time of a counter-day (contre-temps $d u$ contre-jour) a later phenomenologist would say. ${ }^{64}$ At issue is the heart of time that only literature has the licence to explore affirmatively; hence the need to grasp the inverse relation between the sovereignty of literature and the literary state of exception, on the one hand, and the regular rule of law, on the other.

The law is not shallow then. What comes across or appears as shallow legality is merely the end result of the constructive Kelsenian purification through which law keeps the literary depths of life at bay. In other words, what comes across as shallow legality is the outward manifestation of its inverse depth. The law deals with life and death and the depths of life and death from the purified vantage point of its legalistic end results or end phases. This purified vantage point also allows the law to deal with life that manifestly lacks depth. For life can indeed also be banal and shallow, as Arendt observed with reference to Adolf Eichmann. ${ }^{65}$ In fact, the purified vantage point of constructed law is exactly what allows law to deal with the apparent puzzles that Arendt raises in response to the Eichmann trial. Three apparent puzzles are at stake here, none of which poses a real dilemma for the Arendtian/Kelsenian conception of law that we are developing here. The first concerns the observation that the law is not equipped to deal with crimes of the scale of the Holocaust, "that it was pointless to impose the death sentence for crimes of such magnitude." 66 The second concerns the manifest absence of mens rea in the case of Eichmann. The third

\footnotetext{
${ }^{62}$ I am thankful to Lawrence Douglass for probing questions that prompted me to rethink and rewrite this part of the paper substantially after the Antwerp workshop on Arendt and the Law, June 2010.

${ }^{63}$ Compare Frank Michelman's take on Rawls in this regard: "[Constitutionalism] hopes to vault people past their real, unliquidated disagreements and uncertainties regarding the actual, substantial merits - the all things considered rigthness, goodness, or prudence of ... laws and other legal acts.... It invites the parties to such disagreements and uncertainties to slide past them, 'get over' them...." Cf. Michelman "Constitutional Legitimation for Political Acts" (2003) 66 Modern Law Review 1, 6-8. ${ }^{64}$ Derrida Politiques de l'amitié (Paris, Éditions Galilée 1994) 31.

${ }^{65} \mathrm{Cf}$. Arendt Eichmann in Jerusalem 49, 252, 287-288. On these pages Arendt refers to Eichmann's sheer inability to think and the banal thoughtlessness of his evil deeds. She does not use the word "shallow" here, but she does so when she returns to her experience of Eichmann in The Life of the Mind at 4: "I was struck by a manifest shallowness in the doer that made it impossible to trace the uncontestable evil of his deeds to any deeper level of roots or motives."

${ }^{66}$ Arendt Eichmann in Jerusalem 250.
} 
concerns the problem of retroactivity, the problem of convicting someone of a crime that had no positive legal existence at the time it was committed.

Arendt credits the first puzzle with some merit: "[It is] true in a sense, except that it could not conceivably mean that he who had murdered millions should for this very reason escape punishment." ${ }^{, 67}$ Quite in contrast to Arendt, the understanding of law that emerges from the phenomenological reflection on her thought above credits the argument with no such merit. The negative or inverse depth of the law demands that it views the parity between crime and punishment as a secondary concern in the case of all serious or "capital" crimes. From the vantage point of its inverse depth, it knows well that it cannot fathom the crime and should therefore not endeavour to meet it with "adequate punishment". Effective punishment suffices. Effective punishment could consist in any significant degree of sacrificial relief (vengeance) offered to victims and those connected to them, ${ }^{68}$ any significant degree of deterrence offered to future criminals and any degree of rehabilitation that it may bring about. And the question from this point of view would of course always be whether long term or life imprisonment would not have been more effective on all counts in Eichmann's case. Who knows whether even this man, according to Arendt so completely incapable of thought, might not have come to have "some thoughts" after ten or twenty years in jail?

The second puzzle concerns Eichmann's apparent lack of mens rea. Arendt makes mention of the subjective element - the intent to do wrong - of the crime that all modern legal systems take as a precondition for criminal conviction and suggests that it was absent in Eichmann's case. ${ }^{69}$ She was not a lawyer or legal theorist and it is understandable that she would not have engaged with the finer aspects of the legal debates of her time on mens rea. That is probably why she failed to observe that the "subjective element" of mens rea was no longer understood to be that "subjective" by the time Eichmann stood trial. The theory of criminal law had by that time largely moved away from the "psychological" approach to mens rea that was current in the nineteenth century. The "normative" approach to mens rea that became dominant in the twentieth century, quite expressly gave up on the idea that the state of mind of the accused could be proved. Sufficient for a finding of mens rea, the new approach held, was the application of norms of assessment or presumptions regarding the criminal state of mind. Central to these was the presumption that the accused willed the natural consequences of his actions. ${ }^{70}$ This was of course not the problem in the Eichmann trial. Eichmann's defence was not that he did not intend to murder or did not know that killing would ensue from his actions. His defence was that he had no consciousness of doing wrong. He merely and dutifully executed decisions taken and orders issued by others. But here too does contemporary criminal law resort to constructions. Mere obedience to a manifestly unlawful command does not count as a defence in law, postulates the applicable rule. As to the question what constitutes a "manifestly unlawful command", the rule states further: Manifestly unlawful is that which a reasonable person would deem manifestly unlawful. The law, in other words,

\footnotetext{
67 ibid.

${ }^{68}$ Vengeance should of course play no role in punishment according to contemporary theories of sentencing, but a phenomenology of law would probably doubt whether such a completely nonsacrificial conception of law is realistic.

${ }^{69}$ Arendt Eichmann in Jerusalem 277.

${ }^{70}$ For textual references to this development in criminal theory, cf. Van der Walt "Agaat's law" 721.
} 
was not at all concerned with Eichmann's subjective assessment of the lawfulness of the murderous commands that he obeyed. It was concerned with an objective standard: how would reasonable persons generally assess commands like those Eichmann executed?

Thus does the law deal with crime without having to probe either its hidden depths or its sheer banality. In a profound sense, or negatively or inversely profound sense, it judges only acts perpetrated and not the perpetrators of acts. From the perspective of the law, it matters little whether Eichmann's motivation was sublime or banal. From the perspective of law it also matters little whether he really had knowledge of wrongfulness or not. The law simply subjected him to an objective standard regarding the state of mind he should have had. But the troublesome questions are not solved fully yet. What if the whole context of action was so corrupt that this objective standard of the reasonable person could not be applied? What if that which we today deem to be utterly and atrociously unreasonable was generally deemed reasonable at the time? This is the deep end of Arendt's concern with the legal coherence of the Eichmann trial:

"If we are to apply this whole reasoning to the Eichmann case in a meaningful way, we are forced to conclude that Eichmann acted fully within the framework of the kind of judgment required of him: he acted in accordance with the rule, examined the order issued to him for its 'manifest' legality, namely regularity; he did not have to fall back on his 'conscience', since he was not one of those who were unfamiliar with the laws of his country." 71

In other words, there was no discrepancy between the commands Eichmann executed and the law he knew and took for granted. One can see now how the question regarding Eichmann's state of mind leads straight into the question of the nonretroactivity of criminal legislation - nullum crimen, nulla poena sine lege, as it must. But the phenomenological reflection on Arendt and the law must remain puzzled by Arendt's concern in this regard. ${ }^{72}$ She pays considerable attention to the problem of non-retroactivity. She cites extensively in this regard the reflections of the court on the retroactivity of the Israeli legislation applied during the Eichmann trial - the Nazis and Nazi Collaborators (Punishment) Law of 1950 - and the London Agreement of 1945 that was applied during the Nuremberg Trials:

\footnotetext{
“"This particular legislation', the judgment pointed out, 'is totally different from any other legislation usual in criminal codes,' and the reason for its difference lies in the nature of the crimes it deals with. Its retroactivity, one may add, violates only formally, not substantially, the principle nullum crimen, nulla poena sine lege, since this applies meaningfully only to acts known to the legislator; if a crime unknown before, such as genocide, suddenly makes its appearance, justice itself demands a judgment according to new law.",73
}

\footnotetext{
${ }^{71}$ Arendt Eichmann in Jerusalem 293.

${ }^{72}$ As it also cannot but be puzzled by the exuberant and self-indulgent moral lesson she contrived for the "proper sentencing" of Adolf Eichmann - why on earth should one endeavour to expound "profound" considerations of "sharing the earth" for the conviction of one whom one has already considered to be irredeemably banal and shallow? Would the inverse or negative depth of the law not have required that the sentencing of Eichmann be accompanied by nothing more than a silent gesture of sheer disbelief and dismay, perhaps nothing more than a barely noticeable shrug of a shoulder? Is it because Arendt seeks to express and make manifest here what should not be expressed and made manifest; is it because she is expressing her own heart here, that her sentencing of Eichmann itself comes across as painfully shallow? Cf. Arendt Eichmann in Jerusalem 277-279.

${ }^{73}$ Arendt Eichmann in Jerusalem 254. Cf. also 272-273.
} 
One should not be mislead by the spurious logic of this reasoning. Why, can one ask, would this reasoning not be applicable to just about every instance in which one might want to invoke the principle of nullum crimen, nulla poena sine lege? One what basis can it be said that the principle only applies to acts that are pervasively and enduringly known before they are criminalised? The problem of new crimes surely does not always relate to acts that have existed conspicuously and enduringly. They often relate to new manifestations of human deviousness with which legislators have not been confronted before. The fact that they also sometimes concern the criminalisation of long-existing social practices as a result of changing moralities surely does not warrant the rule the court invoked in the Eichmann trial. Arendt quite understandably observes that "the discussion of these matters has remained somewhat confused.",74 Remarkable however, is her failure to invoke in this regard a more forceful explanation why the principle of non-retroactivity should not apply to crimes such as those committed by Eichmann. For central to her thinking about law and the foundations of law, as we have seen above, is a principle that goes to the heart of the matter at issue here. The foundations of law may be eclipsed in dark times. They may not always be self-evident. They may require revolutionary re-founding from time to time. But when they are thus re-founded, they are again held to be self-evident, however much we realise increasingly as history progresses that they are not always self-evident. We saw above how central this point is to her argument in $O n$ Revolution. Consider now the way she phrased it already eight years earlier in Men in Dark Times:

"The most frightful errors have replaced the 'best-known truths', and the error of these doctrines constitutes no proof, no new pillar for the old truths ... [And] it is likewise inevitable that ... people's mistrust of the world and all aspects of the public realm should grow steadily. For the fragility of these repeatedly restored props of the public order is bound to become more apparent after every collapse, so that ultimately the public order is based on people's holding as self-evident precisely those 'best known truths' which secretly scarcely anyone still believes in." ${ }^{, 75}$

The regard for the sheer performativity of law, the Kelsenian move of acting as if there is law, the act of faith that founds the law, can hardly be articulated more forcefully than Arendt does it here. But this is the remarkable thing about this Kelsenian move: the universality and timelessness that it demands despite its fragile and contingent origins. Once cannot hold truths as self-evident and concede at the same time, perhaps because of empirical pressures, that others did not see them as self-evident. One either holds them as self-evident or one does not. And when one truly does so, one quite simply cannot at the same time exempt others from this selfevidence without contradicting oneself. Holding a truth as self-evident demands imposing this assumed self-evidence on others. In fact, as we saw from this passage from Men in Dark Times, holding a truth as self-evident may even require imposing it on ourselves, for we too may not always see them as self-evident. That is also why, for our own sake and the sake of others, as Rawls teaches us, we should not hold too many truths as self-evident. But this is another issue. The important thing to grasp here is this: If we hold it as self-evident that Eichmann's acts constituted the gravest of crimes, we hold it as self-evident for everyone, also for Eichmann and his generation of Germans. That is the meaning of self-evidence. It cannot have another

\footnotetext{
${ }^{74}$ ibid at 255 .

${ }^{75}$ Cf. Arendt Men in Dark Times (Middlesex, Penquin Books, 1973) 19.
} 
meaning. Once one has grasped this point, the principle of non-retroactivity should no longer concern us in cases such as Eichmann's. ${ }^{76}$

This is what is ultimately at issue in the concept of common sense judgment about right and wrong that Arendt develops with reference to Kant's theory of judgment. At issue in judgment is never just a question of what "I think", but always a matter of thinking or imagining what others also think or would think. In other words, judgment is indeed about common sense. ${ }^{77}$ As such, it turns on the same communality that informs, according to Merleau-Ponty, basic acts of perception and the faith that we invest in our basic perceptions, the faith that we share the same world. Merleau-Ponty insists with reference to Husserl on the condition of the self as "precluded from becoming an absolute individual" (qui m'empêche d'être absolument individu), as "exposed to the regard of others as a man among men" ( $m$ 'expose au regard des autres comme un homme parmi les hommes), as "one consciousness among many" (une conscience parmi les consciences). ${ }^{78}$ The conviction that we are not nothing (de n'être rien) and indeed exist in the world in the way we do (de ne vivre qu'en parasite du monde, d'habiter un corps et une situation) turns on this fundamental communality of perception and on the experience of being perceived by others (l'expérience $d u$ regard d'autrui sur moi). ${ }^{79}$

Arendt endorsed this communality of experience expressly:

“Our 'perceptual faith', as Merleau-Ponty has called it, our certainty that what we perceive has an existence independent of the act of perceiving, depends entirely on the object's also appearing as such to others and being acknowledged by them. Without this tacit acknowledgment by others we would not even be able to put faith in the way we appear to ourselves." 80

The historical or empirical encounter with some individuals, even a generation of individuals, who made a mad mockery of the basic precepts of common experience and common judgment surely served to shake these precepts to their roots. "Do we all still live in the same world?" is a question one may well be inclined to ask after Auschwitz. But those who survived unscathed enough to re-invest faith in a common world can only do so with resort to common sense judgments regarding common humanity, common decency and common criminality, on the one hand, and literary explorations of the depths of depravity, on the other. In fact, the latter explorations were clearly better left to those who did not survive unscathed enough, who never quite returned to a common world of self-evidence. It was up to Celan, amongst others, not the law, to probe the black holes of and before time that haunted the Nuremburg and Eichmann trials; the black milk of the dawn - schwarze Milch der Fruhe - that spawned the post-Auschwitz times that remain ours. ${ }^{81}$

\footnotetext{
${ }^{76}$ It is in this respect that not only Americans, but all of humanity must understand themselves to be "always under law" as Michelman contends, even when they are not. Cf. Michelman "Always under law? (constitutional democracy)" (1995) 12 Constitutional Commentary 227-47; "Can constitutional Democrats be Legal Positivists? Or why Constitutionalism" (1996) 2 Constellations 292-308.

${ }^{77}$ Cf. Arendt Responsibility and Judgment (New York, Schocken Books, 2003) 137-143.

${ }^{78}$ Merleau-Ponty Phénoménologie de la Perception 12-13.

${ }^{79}$ Merleau-Ponty Le visible et l'invisible 89.

${ }^{80}$ Arendt The Life of the Mind 46.

${ }^{81}$ Cf. Paul Celan Gesammelte Werke I (Frankfurt am Main, Suhrkamp, 1983) 41. This is the time that remains for us, and it will remain the challenge of this time whether we can sometimes live in it, as if not (hos me) living in it, as if there is law, or some law; as if some law remains in the wake of cataclysmic destructions of law. At issue here is not only a Pauline messianism, but also an inversion of
} 


\section{BACK TO THE BEGINNING}

The gap in time, the heart of time, the hiatus; this is the darkness or the source of darkness that Arendt brings to bear in the passage with which our inquiry into Arendt and the law commenced above; the passage in which she describes the relation between the private and the public, indeed, as a passage. The relation between the private and the public, we saw there, consists in the passage from the darkness of the private to the light of the public. This darkness of the hiatus, the heart of time, does it also refer to the darkness of the human heart that Arendt reserves for the explorations of literary narratives? Is the human heart the hiatus? Perhaps. Perhaps it was his own heart that Aeneas was pursuing during his wanderings; his own heart that Virgil was exploring through Aeneas. Perhaps it is their own hearts that the Israelis were pursuing in the desert, are still pursuing today, often at the expense of illuminated or enlightened law and order. Is it accurate to associate these chiasmic pursuits of the heart with the "private" and "private property", as Arendt does? One should note how close she comes to echoing Heidegger's invocation of Eigentlichkeit and, by implication, Eigentum (property), for these authentic pursuits of the heart.

Perhaps it is, from a perspective of law and the legal, not inappropriate to refer to the dark domains of the heart as "the private" that needs to be shielded by property rights - in any case, up to the point that we wish to protect and not prosecute this privacy by law. But considering what is really at stake here, it is a rather un-poetic and shallow way of putting it. One should always remain alert to the way the profoundest of thinkers, and here specifically Arendt and Heidegger, sometimes rush in like lawyers where poets would fear to tread.

\section{BIBLIOGRAPHY}

Agamben, G The Time that Remains. A Commentary on the Letter to the Romans (Standford, Stanford University Press, 2005)

Arendt, H Men in Dark Times (Middlesex, Penquin Books, 1973)

Arendt, H The Origins of Totalitarianism (New York/London, Harcourt Inc, 1976)

Arendt, H The Life of the Mind (New York/London, Harcourt Inc, 1978)

Arendt, H The Human Condition (Chicago/London, University of Chicago Press, 1989)

Arendt, H On Revolution (New York, Penguin Books, 1990)

Arendt, H Eichman in Jerusalem (New York, Penguin Books, 1994)

Arendt, H and Heidegger, M Hannah Arendt Martin Heidegger Briefe 1925 - 1975 (Frankfurt am Main, Vitttorio Klostermann, 1999)

Arendt Responsibility and Judgment (New York, Schocken Books, 2003)

Calvino, I If on a winter's night a traveller (London, Vintage Paper Back, 1988)

Derrrida, J Of Spirit. Heidegger and the Question (Chicago, University of Chicago Press, 1987)

Derrida, J Politiques de l'amitié (Paris, Éditions Galilée 1994)

Heidegger, M Sein und Zeit (Tübingen, Max Niemeyer Verlag, 1979)

Heidegger, M Unterwegs zur Sprache (Pfullingen, Günther Neske 1986).

Heidegger, M Wegmarken (Frankfurt am Main, Vitttorio Klostermann, 1978)

this messianism that Agamben does not contemplate: How to live as if there is law? But Agamben may well have a point when he criticises Adorno for foreclosing this question resentfully. Cf. Agamben The Time that Remains 35-39. 
Heidegger, M Identiät und Differenz (Pfullingen, Günther Neske 1986)

Heidegger, M Der Satz vom Grund (Pfullingen, Günther Neske, 1986)

Heidegger, M Zur Sache des Denkens (Tübingen, Max Niemeyer Verlag 1976)

Husserl, E Die Krisis der europäischen Wissenschaften und die transzendentale Phänomenologie, Husserliana Bd XXIX (Dordrecht/Boston/London, Kluwer Academic Publishers, 1993)

Kelsen, H Reine Rechtslehre. Einleitung in die rechtswissenschaftliche Problematik (Leipzig, Deuticke, 1934)

Lefort, C L'invention démocratique (Paris, Fayard, 1994)

Merleau-Ponty, M Phénoménologie de la Perception (Paris, Gallimard, 1945)

Merleau-Ponty, M Le visible et l'invisible (Paris, Gallimard, 1964)

Michelman, F “Always under law? (constitutional democracy)" (1995) 12 Constitutional Commentary 227-47

Michelman, F "Can constitutional Democrats be Legal Positivists? Or why Constitutionalism" (1996) 2 Constellations 292-308.

Michelman, F “Constitutional Legitimation for Political Acts” (2003) 66 Modern Law Review 1-15.

Posner, R Law and Literature (Cambridge, Massachusetts/London, England, Harvard University Press, 1998)

Rawls, J Political Liberalism (New York, Columbia University Press, 1996).

Schoeman, M Generositeit en Lewenskuns (Pretoria, Fragmente Uitgewers, 2004)

Van der Walt, J “Agaat's Law: Reflections on Law and Literature with Reference to Marlene van Niekerk's Novel Agaat" (2009) 126 South African Law Journal 695-739

Van der Walt, J "The Shadow and its Shade: A response to Ulrike Kistner's paper 'Sovereignty in question"” (2009) 24 South African Public Law 269-296

Van der Walt, J Law and Sacrifice (London/Johannesburg, Cavendish/Wits University Press, 2005) 